\title{
THE LAW UNVEILED: \\ ON BURKA BAN, KANZELPARAGRAPH AND MILITANT SECULARISM IN THE SOCIALIST YUGOSLAVIA
}

\begin{abstract}
Despite being closely examined from the perspective of its political background, the 1950 Yugoslav burka ban as a legal text remained until now beyond interests of historians of law. Exposing this Yugoslav law to a strictly normative analysis and comparison with analogous contemporary bans, this paper delivers the findings that largely exceeded the results of historical studies done so far. Though a brief text, the Yugoslav burka ban was a composite legislation that surely contained full-face veil ban, but also penalized criminal acts against unveiling and introduced an embryo to the future socialist Kanzelparagraph i.e., pulpit law as well. Openly aiming to break a religiously inspired behavior, its militant advocacy was only apparently distinct from a more neutral wording of the present-day veil-bans. A thorough analysis of its ideological foundation, however, indicates a crucial common feature with the modern laical legislation: the paternalistic state action excluding religion as such from the open public space and free debate. As such, the legacy of the Yugoslav socialist burka ban contributes to better understanding of militant secularism as surely a modern, but not a new controversy.
\end{abstract}

Key words: Burka Ban, Kanzelparagraph, socialist Yugoslavia, socialist secularism, militant secularism.

\section{INTRODUCTION}

On 2021 referendum the Swiss voted a general full facial covering ban in public places. Although the proposal did not specifically mention any kind of Islamic garments such as burka or niqab, the related public debate

Associate Professor, Union University Law School Belgrade; e-mail: marko.bozic@ pravnifakultet.rs

The paper is the result of the author's research study conducted at Centre d'études turques, ottomanes, balkaniques et centrasiatiques (CETOBAC), CNRS, Paris, France during the summer of 2021. The author would hereby like to express his special gratitude to Mr. Marc Aymes, the CETOBAC Director, and Ms. Nathalie Clayer, its Research Member. 
was focusing foremost on the Muslim full-face veil. By voting yes, Switzerland has joined the growing club of European nations with the similar legislations, laical France and Belgium heading the list that includes mostly western European countries, but also many regions and municipalities spread all over the Old Continent. ${ }^{1}$

The present-day burka ban is not a new phenomenon, though. In pursuit of modernization, usually assimilated to westernization, the secular regimes in majoritarian Muslim nations such as Atatürk's Turkey, Reza Shah Pahlavi's Iran or King Zog's Albania led campaigns and undertook administrative measures against traditional woman dress in the interwar period. In the eyes of those regimes the full-face veil was a sign of backwardness, associated to female submission and seclusion, while the unveiling was promoted as a path to women's emancipation, but also as a national cause. As a part of struggle for communist revolutionary transformation, a series of similar anti-veiling campaigns were launched from 1920s in Soviet Central Asia and the Caucasus, and after 1945 in the Balkans. $^{2}$ Although ideologically different, all those political regimes, whether nationalist or communist, were opposed to what they viewed as the reactionary forces of Islam and its backward traditions, and all wished to create a new and modern woman, unveiled, educated and integrated into the modern society and workforce. ${ }^{3}$

But, how much does the contemporary burka ban controversy really have in common with that past politics and to what extent can their legacy compare to the analogue present-day legislation? The lack of legal regulation in most of these dominantly Muslim countries, i.e., the absence of formal rules forcing woman to unveil, makes any fact-based comparison less likely. ${ }^{4}$ If there are important studies related to this topic, they mostly

$1 \quad$ France and Belgium voted nationwide face-covering bans in all public places during 2011. After both prohibitions obtained their court approvals from the ECtHR, first in 2014, then again in 2017, a wave of similar legislations hit Europe during the late 2010s: first Bulgaria in 2016, then Austria in 2017, Denmark and the Netherlands during 2018, and finally Switzerland in 2021, adopted their national full-face bans as well. Beside these nationwide bans, there are many, either regional (in Italy or Spain) or partial restrictions of face covering limited only to specific public places, institutions, etc. (Germany, Luxembourg, Bosnia and Herzegovina or Kosovo).

2 Cronin, S., Introduction: coercion or empowerment? Anti-veiling campaigns: a comparative perspective, in: Cronin, S., (ed.), 2014, Anti-Veiling Campaigns in the Muslim World - Gender, Modernism and the Politics of Dress, New York, Routledge, p. 3.

3 Ibid.

4 Most of these regimes resorted rather to the intensive propaganda campaigns then to sartorial laws. There are some exceptions, however: Atatürk's Turkey voted the Hat Law forbidding the fez in 1925 and local councils issued sporadic bans of the peçe and çarşaf. The authorities in Soviet Azerbaijan enacted directives that partially 
concern the examination of government policies or discourse analysis, rarely the scrutiny of normative aspect or judiciary dimension of these affairs. Therefore, the case of the socialist Yugoslav legislation seems inasmuch unique and valuable, but has not been explored enough. Closely inspected from the perspective of its political background, ${ }^{5}$ the $1950 \mathrm{Yu}-$ goslav burka ban as a legal text remained until now beyond interests of historians of law, socialism, region or religion offering an excellent opportunity to this research paper.

Exposing the Yugoslav law to a normative analysis, this study delivers the findings that largely exceeded the results of historical analysis done so far. Though a brief text, the Yugoslav burka ban was a composite legislation that contained a set of penalties aiming to break a religiously inspired disobedience to the new revolutionary order under construction: it obviously enacted the full-face veil ban, but also penalized different criminal acts against unveiling and introduced an embryo to the future socialist pulpit law as well. ${ }^{6}$ More complex than it appears, the analyzed Yugoslav

banned full-face veil in schools or movie theatres. (For more on this, see: Kamp, M., Women-initiated unveiling: state-led campaigns in Uzbekistan and Azerbaijan, in: Cronin, S., (ed.), 2014, Anti-Veiling Campaigns in the Muslim World - Gender, modernism and the politics of dress, New York, Routledge, pp. 205-228). For pros and cons of outlawing the full-face veil during so-called Hujum large-scale campaign in Soviet Central Asia, see: Massell, J. G., 1974, The Surrogate Proletariat - Moslem Women and Revolutionary Strategies in Soviet Central Asia, 1919-1929, Princeton, Princeton University Press, pp. 348-352. In fact, the unique majoritarian Muslim country that voted nationwide burka ban was Kingdom of Albania in 1937. For more on this topic, see: Clayer, N., Behind the veil: the reform of Islam in Interwar Albania or search for a 'modern' and 'European' Islam, in: Cronin, S., (ed.), 2014, Anti-Veiling Campaigns in the Muslim World - Gender, modernism and the politics of dress, p. 234.

5 E.g., Ballinger P., Ghodsee, K., 2011, Socialist Secularism. Religion, Modernity, and Muslim Women's Emancipation in Bulgaria and Yugoslavia, 1945-1991, Aspasia, Vol. 5, No. 1, pp. 6-27; Simić, I., The Veil Lifting Campaign, in: Simić, I., 2018, Soviet Influences on Postwar Yugoslav Gender Policies, Palgrave Macmillan, pp. 155-182; Hadžiristić, T., 2017, Unveiling Muslim Women in Socialist Yugoslavia: The Body between Socialism, Secularism, and Colonialism, Religion \& Gender, Vol. 7, No. 2, pp. 184-203. There are several thoroughly conducted studies dealing with the course and outcomes of the anti-veiling campaign in different regions of Yugoslavia. For Bosnia, see: Jahić, A., Revolucija i emancipacija, in: Jahić, A., 2017, Muslimansko žensko pitanje u Bosni i Hercegovini (1908-1950), Zagreb, Bošnjačko nacionalno vijeće za grad Zagreb, pp. 427-497; For Montenegro, see: Folić, Z., 1999, Skidanje zara i feredže u Crnoj Gori 1947-1953, Istorijski zapisi, Vol. 72, No. 3-4, pp. 73-90; For Serbia, see: Kačar S., 1999, Sudari svjetova (o akciji skidanja zara i feredže u Sandžaku), Almanah, Vol. 2, No. 7-8, pp. 31-44.

6 It is likely that Yugoslav legislation was designed under a certain influence of this 13 years older Albanian model. According to Nathalie Clayer, the Albanian full-face veil ban voted on 8 March 1937 under the title Law on the Ban on Face Covering, "stipulated that it was forbidden for a woman to cover her face, totally or partially, with any 
law of 1950 discloses a broader political agenda that is hidden behind it: a militant secularism of the young socialist state that did not hesitate to subdue the religion in order to ensure its own prosperity.

\section{The Yugoslav Laws}

Strictly speaking, there has never been anything as the Yugoslav burka ban. As a federation, the socialist Yugoslavia was formed of six federated states, so called 'republics', and only four of them - first Bosnia in late September, then Montenegro in November 1950, and finally Macedonia and Serbia in January 1951, voted their state legislation forbidding the full-face veil in public. ${ }^{7}$ No similar federal, i.e., Yugoslav nationwide legislation had been voted at any time before or afterwards. On the other hand, no federal legislation abrogated these statutes either, formally still binding today.

Nevertheless, the fact that all four legislations shared the similar, almost identical form and substance, justifies their Yugoslav label: less an expression of the state particularism, but a coordinated response to the common challenge. It is already the identical choice of their titles -Law on Ban of Wearing the Zar and the Feredža $a^{8}$ that indicates a joined cultural and historical background of the Ottoman Balkans. ${ }^{9}$ The structure of all

kind of veil. Offenders, as well as the husbands, fathers, or guardians who had not exerted their authority and those who were making propaganda in favor of the veil, incurred a fine.", Clayer, N., 2014, p. 234. This hypothesis seems as much plausible since the Yugoslav unveiling campaign started first in Kosovo, in late 1945.

7 Zakon o zabrani nošenja zara i feredže [Law on Ban of Wearing the Zar and the Feredža], Službeni list NR Bosne i Hercegovine [Official Gazette of PR Bosnia and Hercegovina], No. 32/50, p. 427; Закон о забрани ношења зара и фереџе [Law on Ban of Wearing the Zar and the Feredža], Службени листи НР Црне Горе [Official Gazette of PR Montenegro], No. 31/50, p. 229; Закон о забрани ношења зара и фереџе [Law on Ban of Wearing the Zar and the Feredža], Службени іласник НР Cpбuje [Official Gazette of PR Serbia], No. 4/51, pp. 84 and 85; Закон за забрана да се носи зар и фереџе [Law on Ban of Wearing the Zar and the Feredža], Службени весник на НР Макеgонија [Official Gazette of PR Macedonia], No. 1/51, p. 1.

8 It is interesting to notice that the same semantics were adopted by the Macedonian legislator regardless of the fact that these garments in Macedonia were traditionally known as čaršaf and peča.

9 Not quite similar to the burka of the Afghan origin, the Balkans' zar [from the Turkish word $z a r$ that derived from the Arabic word izār] and feredža [from the Turkish word ferace that derived from the Arabic word färäğiyyä developed in its turn from färäg - consolation] designated a fabric cloak or hooded coat. Interestingly enough, it seems that there is no consent what those garments were really like. Škaljić, A., 1985, Turcizmi u srpskohrvatskom-hrvatskosrpskom jeziku, Sarajevo, Svjetlost, pp. 279-647; Klajn, I., Šipka, M., 2006, Veliki rečnik stranih reči i izraza, Novi Sad, Prometej, pp. 473 and 1314; Kačar S., 1999, pp. 32-33. 
four legal acts is almost the same: a brief, paragraph-long prolegomenon explaining the legislator's drivers precedes the two general prohibitions wearing the full-face veil (Art. 1), and forcing or persuading woman to wear the full-face veil (Art. 2). The core of the law, however, is four penalties coming from these two prohibitions: two infractions and two criminal offenses (Arts. 3 and 4), each of them deserving an analysis. Finally, all four legislations contained series of closing articles (Arts. 5-7) that established criminal jurisdiction over criminal cases envisaged by the law and set a law vacation of 30 days. The slight differences related to nomotechnique (the rules regarding the criminal jurisdiction were divided in two distinctive articles by the Bosnian, Montenegrin and Macedonian, however they were merged in a single article by the Serbian legislator), semantics (especially in the Macedonian, less in the Montenegrin text) or runtime of law vacation (sixty instead of thirty days, in the Serbian case) did not affect the initial sense provided by the Bosnian statute as the first adopted one, thus, a model law.

\subsection{PROLEGOMENON}

Although all four Yugoslav statutes contained the similar prolegomena exposing legislator's aims in a brief and similar way, those introductory texts were not completely identical either in their form or substance. The first article in the Bosnian statute, as the first adopted one, set a model which was not strictly copied by the three other legislators. The Montenegrin National Assembly restated almost ad verbatim the Bosnian prolegomenon. However, they integrated it within the pertinent promulgation decree, not in the statute itself. Last voted, the Serbian statute adopted this Montenegrin nomotechnique, but considerably complemented the content of the Bosnian narrative. Regardless of these formal and substantive differences, all four prolegomena were justifying the purpose of the fullface veil ban in the same way: as an act of Muslim women's emancipation through the intervention of the paternalistic state.

\subsubsection{An Explicit Goal: Muslim Women's Emancipation}

Unlike the modern burka ban controversy, marked by a complex legal argumentation and political advocacy, the analogous Yugoslav law had a single and unique purpose: Muslim women's emancipation. The prolegomena of all four Yugoslav statutes univocally stated the three common goals this legal ban was about to achieve: the elimination of veil as centuries old sign of submission and backwardness in order to accomplish the full 
gender equality, ${ }^{10}$ the better accessibility of women to their constitutional rights ${ }^{11}$ and the broader participation of women in social, cultural and economic life of the state. Similarly, all four introductory texts legitimized the legal ban as a due response of the socialist state to the manifested demands of people's masses, working collectives and mass organizations but also, in Serbian case, to the expressed will of political, dominantly Muslim, representatives of Autonomous Region of Kosovo and Metohija.

High on the list of declared goals, in all four texts, was the elimination of veil as a sign of cultural backwardness associated with the old patriarchal and religiously inspired social order that the postwar socialism-under-construction intended to liquidate. As the outward symbol, the veil relegated women strictly to home life ${ }^{12}$ and it was closely identified with the female seclusion and segregation. Accordingly, the unveiling was the objective of a large-scale state-orchestrated campaign led by the Anti-Fascist Women's Front aiming to close the gap between the rights recognized by the new socialist constitution and the reality of everyday lives of women. ${ }^{13}$ Faced with the limited success of the campaign that first started in Kosovo right after the liberation in 1945, and spread to Bosnia and Montenegro by the summer of $1947,{ }^{14}$ the state authorities decided to resort to legal coercion, i.e., to outlaw wearing of the full-face veil as a reactionary clothing practice.

Seen as 'an intrinsic component' ${ }^{15}$ or 'a measure'16 of socialist modernization, women's emancipation and unveiling in the postwar Yugoslavia easily recall the main discursive elements and strategies that marked the contemporary burka ban debates, gender equality in the first place. However, on closer inspection, the Yugoslav legal text discloses a distinct logic

10 Naturally, in socialist Yugoslavia during the early 1950s there could have not been any mention of gender equality. Precisely, the Bosnian and the Montenegrin statutes referred to the women's equality, the Macedonian statute mentioned the equality of sexes, while the Serbian one stipulated "the equality between man and woman as a constitutional principle".

11 Actually, the Macedonian statute did not recognize this goal at all, while three other legislations defined it in significantly different way: While the Serbian statute stipulated "rights granted by legal and social order of our socialist fatherland", the Bosnian and the Montenegrin statute referred to "rights gained through the People's Liberation War and through the building of socialism".

12 Hadžiristić, T., 2017, p. 193.

13 Ibid., p. 190.

14 Jahić, A., 2017, pp. 455 and 456; Folić, Z., 1999, p. 79.

15 Bonfiglioli, C., 2012, Revolutionary Networks. Women's Political and Social Activism in Cold War Italy and Yugoslavia (1945-1957), doctoral dissertation, Utrecht University, p. 192.

16 Ballinger P., Ghodsee, K., 2011, p. 21. 
of socialist modernization. A prominent place that all four prolegomena left for 'economic life', 'working collectives' and 'building of socialism' refers primarily to women's emancipation as an economic and not only a political issue. In the Marxist optic, determined by the invisible laws of dialectical materialism, conditio humana is a consequence of a man's or woman's position in the chain of control over resources and means of production: individuals are politically free inasmuch as they are economically emancipated. The new socialist state defined as the dictatorship of the proletariat granted the monopoly over political power to the working class from which the veiled Muslim women were excluded: unrecognizable under the veil, they could not undertake the working tasks nor take credits and assume any individual responsibilities. ${ }^{17}$ To achieve their political subjectivity, Muslim women must join the labor force first. ${ }^{18}$ It is no wonder then that many of women's rights were dealt via labor laws ${ }^{19}$ and that the postwar recovery planning was closely associated to the anti-veil campaign all over the country. ${ }^{20}$

The Muslim headscarf as an economic, rather than an exclusively political issue, was not the only distinctive point of the Yugoslav anti-veil politics and legislation. This discourse deviates from its contemporary and western counterpart so much so that these four prolegomena did not mention any other justifying political principle or social value but gender equality. More precisely, the socialist modernization did not enact fullveil ban in order to protect the public order, security or safety threatened by any kind of 'weapon under burka' terrorism. ${ }^{21}$ Its aim was not the

17 In order to support their claims, the actors of the Yugoslav anti-veil campaign emphasized an urban background of covering a woman's face that peasant women have never fully adopted since it disturbed them to perform daily tasks their livelihoods depended on (Hadžiristić, T, 2017, p. 193). The similar argument had been evoked in Russia long before the similar Soviet Hujum campaign took place in Central Asia (Kamp, M., 2014, p. 209) as well as by the Arab secularist movement from the end of $19^{\text {th }}$ century in the Middle East (Behiery, V., 2014, A Short History of the (Muslim) Veil, Implicit Religion, Vol. 16, No. 4, pp. 421-422).

18 The manpower shortage in the years of post-war reconstruction provided a strong argument to this theoretical concept. Namely, the women contribution to the success of the ambitious Five-Year Plan of Tito's government was an explicit motive of Yugoslav unveiling campaign whose actors claimed that the Plan "cannot be successful while tens of thousands of women remain veiled” (Hadžiristić, T., 2017, p. 193).

19 Milinović, D., Petakov, Z., 2010, Partizanke: žene u Narodnooslobodilačkoj borbi, Novi Sad, Cenzura \& Rosa Luxemburg Stiftung, p. 80.

20 For Bosnia, see: Jahić, A., 2017, pp. 456-459. For Montenegro, see: Folić, Z., 1999, pp. 78,81 and $84-86$.

21 Seemingly, terrorism as an argument was not completely absent from the socialist case-law related to unveiling campaigns: during the late 1920s and the early 1930s, the Soviet courts in Central Asia qualified the acts committed by fundamentalists 
protection of rights and freedoms of others, either. The presence of veiled women in communist Yugoslavia was not considered as an act of radical propaganda that exerted undue pressure on those who did not wear a veil. Certainly, the loud absence of these modern drivers could be easily explained by their affiliation to substantially different discourse of human rights and democracy. However, it also discloses something else: unlike some contemporary democracy that disputes the veil in order to protect its anchor values such as advanced gender equality, socialist Yugoslavia challenged the veil so as to establish the new values, including the gender equality that did not exist here any time before. In other words, while some western liberal democracies resort to burka ban to defend the freedom, supposedly under the threat coming from a tiny radicalized minority, ${ }^{22}$ the people's democracies from the European East had been facing a widespread tradition and using the ban as an avenue towards the freedom yet to be gained. The Yugoslav ban was a matter of conquering, not defending the liberty. This asymmetry may explain both, the unquestionable success that the Yugoslav ban achieved in the early $1950 \mathrm{~s},{ }^{23}$ and the defectiveness of gender equality argument before ECtHR today. ${ }^{24}$ On the other hand, it should not deceive a symmetric point too. Then and now as well, the bottom line of both politics was exactly the same: the paternalistic state going against the autonomy of an individual's free will.

against unveiled women as the crimes of counterrevolutionary terrorism. Northrop, D., 2004, Veiled Empire, Gender \& Power in Stalinist Central Asia, Ithaca and London, Cornell University Press, pp. 257-258.

22 In all western states that voted nationwide ban in public space, the full-face veiling is a marginal phenomenon. For instance, the Belgium ban of 2011 targeted no more than 200 women. Similarly, the French law of 2010 regulated the practice of less than 2,000 women. In the Netherlands, no more than 300 women were thought to wear full-face veils when the ban was enacted in 2016. The Austrian ban was voted in 2017 albeit the number of women wearing it at that moment was no more than 150 . Mancini, S., European Law and the Veil: Muslim Women from Victims to Emblems of the Enemy, in: Melloni, A., Cadeddu, F., (eds.), 2019, Religious Literacy, Law and History. Perspectives on European Pluralistic Societies, New York, Routledge, p. 129.

23 For more details on enforcement of the Yugoslav full-face ban, see: Karčić, F., 2013, Primjena zakona o zabrani nošenja zara i feredže u Bosni i Hercegovini, Novi Muallim, Vol. 14. No. 56, pp. 50-55; About the enforcement of Yugoslav full-face ban from the perspective of unveiled women, see: Kačar S., 2001, Zarozavanje zara, Podgorica, Almanah, or Kladničanin, F., 2020, Peča, Novi Pazar, Akademska inicijativa Forum 10.

24 The court rejected the women protective argument, claiming that "a State Party cannot invoke gender equality in order to ban a practice that is defended by women such as the applicant - in the context of the exercise of the rights enshrined in those provisions (Article $8 \mathrm{ECHR}$ on private life and Article $9 \mathrm{ECHR}$ on religious freedom - EB), unless it was to be understood that individuals could be protected on that basis from the exercise of their own fundamental rights and freedoms" (ECtHR, SAS v. France, No. 43835/11, Judgement of 1 July 2014, [GB] para. 119). 


\subsubsection{An Implicit Means: Paternalistic Legislation}

The liberal democratic paradigm sees personal autonomy as an ultimate condition of human wellbeing. Although it allows some exceptions such as the concept of militant democracy restraining the individual liberties of those who use them in a way to destroy liberal order, the liberal democracy in principle lets everybody free to make their life choices on personal convictions as long as it does not harm others. Hence, the gender equality can be widely used against another, but not against women's own decision to wear the face-veil voluntarily. ${ }^{25}$ In attempt to remove this objection, the contemporary burka ban advocacy invokes the rights of others or public order as the arguments mentioned above. Aware of insufficiency of this reasoning, ${ }^{26}$ some defenders of the contemporary full-face veil ban call on a laical, secular or, religiously neutral nature of modern state, public school or space. ${ }^{27}$ It is precisely this argument that the socialist legislation implicitly invoked too.

The French term laïcité, derives from the Greek word laos which designates a people considered as an indivisible whole, i.e., a republican nation who does not tolerate communitarian deviations. As Joan Wallach Scott brilliantly pointed out "The basis for French republican theory is the autonomous individual who exists prior to his or her choices of lifestyle, values, and politics; these are but external expressions of a fixed inner self, a self which by definition cannot relinquish its autonomy". ${ }^{28}$ What led French legislator to the full-face veil ban was the conviction that the veiled women were captives in a culture that held them against their will and that was

25 Barton, D., 2012, Is the French Burka Ban Compatible with International Human Rights Law Standards? Essex Human Rights Review, Vol. 9, No. 1, p. 16.

26 For the critical analysis of advocacy in favor of the burka ban in France, see Ibid. So far ECtHR has been more reserved regarding the use of public safety argument. The court ruled that the full-face ban was a disproportionate measure since public safety "could be attained by a mere obligation to show their face and to identify themselves where a risk for the safety of persons and property has been established, or where particular circumstances entail a suspicion of identity fraud" (ECtHR, S. A. S. v. France, No. 43835/11, Judgement of 1 July 2014, [GC] para. 139). As for invoking of protection of the rights and freedom of others, see fn. 31 bellow.

27 Usually associated with France and other countries defined as laical or secular by their constitutions such as Belgium or Turkey, this kind of argument is more widespread than it is most often thought. For its use in the German legal discourse related to the Muslim veil controversy see: Möschel, M., Veiled Issues in European Courts, in: Calvi, G., Fadil, N., (eds.), 2011, Politics of Diversity. Sexual and Religious Self-Fashioning in Contemporary and Historical Contexts, Florence, European University Institute, Department for History and Civilization, pp. 6-8.

28 Wallach Scott, J., 2007, The Politics of The Veil, Princeton and Oxford, Princeton University Press, p. 127. 
the responsibility of the Republic to set them free. ${ }^{29}$ According to this paternalistic viewpoint, it is the society's responsibility to correct its ill-thinking members and protect a man's or woman's human dignity even if it goes against their own will. This state approach "[...] tries to liberate oppressed human beings from impositions of an ideology (e.g., religion or male dominance) in order to offer them another yoke that they should 'freely' accept (e.g., the values of the French Republic)". ${ }^{30}$ Reluctant to public safety and gender equality arguments, the ECtHR curiously proved inclination to this kind of argumentation finding the ban 'socially protective' inasmuch as the full-face veiling undermines the French or Belgium standards of civility. ${ }^{31}$

To all appearances, neither the Yugoslav full-faced veil ban nor the socialist ideology which hides behind it, did incorporate any terms similar to this laical reasoning. The inner logic of the Marxist worldview, however, suggests another assumption. According to the mainstream of the Marxist theory there is no single man or woman who can possibly resist to the invisible hand of universal laws of dialectics shaping the human history since the dawn of the time. Therefore, the revolutionary socialist state on the mission toward women's emancipation was not a matter of voluntarism, but a result of historical determinism. In line of this, socalled scientific socialism, any resistance to socialist modernization is only a reactionary cramp that might slow down the progress of humankind but cannot really change the course of history. The Communist party as a social avant-garde and the law it promotes only catalyze the social process that has already been spontaneously running. Finally, a man or woman shall be free, if they must, against their own will.

\subsection{PENALTIES}

Following the prolegomenon, the main text of the law was composed, almost identically, in all four Yugoslav statutes. Firstly, it provided two

\section{Ibid.}

30 Barton, D., 2012, p. 18.

31 Mancini, S., 2019, p. 136. More precisely, the ECtHR interpreted the argument concerning the rights and freedoms of others in perspective of a wide margin of appreciation to the French and Belgium national authorities, a.k.a. the laical state concept. That is how so-called living together argument is accepted. According to the latter, the full-face veil is harmful to others since it "shocked the majority of the French population because it infringed the principle of gender equality as generally accepted in France" (ECtHR, S. A. S. v. France, No. 43835/11, Judgement of 1 July 2014, [GC] paras. 116-122; Or: "while it is controversial, and undeniably presents risks in terms of the promotion of tolerance in society, [the ban] can be considered as proportionate to the aim it serves, to know the preservation of the conditions of living together" (ECtHR, Belcacemi and Oussar v. Belgique, No. 37798/13, Judgement of 11 July 2017, para. 61). 
general prohibitions - for wearing the veil and forcing or persuading a woman to wear the veil, next the law envisaged a series of penalties of different gravity: infraction consisted of wearing the veil and two criminal offenses that were defined as coercing women to wear the veil and doing propaganda in favor of this prohibited practice.

\subsubsection{Wearing the Veil - a Political or a Religious Issue}

Wearing the veil was prohibited by Art. 1 in all four statutes as an "interdiction of wearing the zar and feredža or of any other way of covering a woman's face". Two infractions provided by Art 3. derived from the prohibition. The first concerned the veiled woman herself, while the second involved all woman's inmates who demanded from her to wear the veil. Both infractions were sanctioned in an identical way: alternatively, by up to three months of imprisonment, or by a medium fine of 20,000 dinars.

The diction of these two articles may suggest a conclusion that Yugoslav legislators in the early 1950s shared similar concerns that bother their present-day western counterparts as well: the above-mentioned prohibition did not focus only on the garments that semantically corresponded to a traditional Muslim woman's attire - zar and feredža, but explicitly forbade every other way of covering of the woman's face without exception. Actually, the French, as any other contemporary burka ban, does not refer to burka (or any other piece of clothing) at all and scrupulously avoids a wording that might give to law an anti-Islamic or, in general, an antireligious connotation: the object of prohibition is any kind of full-face covering as such, whatever might be its ideological meaning. In other words, the contemporary restriction of burka as a religious practice is only a side effect of a law of general application, not the specific aim of an arbitrary legislation: by carefully selecting the legal terms, modern legislators try to decline the assumptions for making discrimination on religious basis. Furthermore, to remove all doubt, the French legislator harmonized its action with the opinions of the Muslim religious authorities. The latter took a stand against an interpretation of the Islamic full-face veiling as a compulsory religious practice, and declared it to be a mere customary habit instead. ${ }^{32}$ By referring to "every other way of covering a woman's face" and by obtaining the supporting opinion from the national and local

32 Although firmly opposed to the legal ban, Mohammed Moussaoui, the head of the French Council of the Muslim Faith (CFCM), has supported taking steps to discourage the tiny minority of Muslim women from wearing the full-face veil. He has been repeating that the full-face veil is not a religious obligation and that is out of place in France. 
Muslim religious authorities, the Yugoslav legislators apparently were trying the same strategy. Being less cautious though, they failed twice.

Unlike the French one, the wording of the Yugoslav ban was obviously aiming at a particular religious practice. Even though it referred to "every other way of covering a woman's face", the law specifically pointed out the $z a r$ and the feredža as evidently the Muslim clothing traditions. Besides, the legal prohibition explicitly deals only with covering of woman's face, which, all along with the prolegomenon, ${ }^{33}$ leads to the conclusion that the Yugoslav law, however, aimed at specific individuals - Muslim women. ${ }^{34}$ Finally, this legislation was adopted only in the four Yugoslav republics with significant Muslim population, but neither in Slovenia nor Croatia.

The fact that the leadership of Muslim religious community in $\mathrm{Yu}-$ goslavia undividedly denounced the full-face veiling as an anachronistic habit of foreign origin ${ }^{35}$ maybe had a crucial impact for the later success

33 It is noteworthy that the prolegomenon of the Serbian statute mentions explicitly the support to the ban coming from the Muslim population regardless of its ethnic origin. In other words, the full-face veil ban was not a decision made by the Belgrade government but an aspiration of the Albanian, Bosniak, Roma and of some other Muslim minorities living in Serbia.

34 The fact that neither catholic nor orthodox women at the time wore the full-face veil, made impression on the Yugoslav Christian women to liberate their oppressed Muslim sisters. It gave ground to rethinking a postcolonial or an orientalist meaning of unveiling campaign in socialist Yugoslavia as inspired by the Western secularism struggling with the Eastern backwardness. However, as Tea Hadžiristić observed "Whereas the modernizing reforms in Iran and Turkey, for example, were concerned with assimilating into a modern European framework and a secular liberalism, those in Yugoslavia were not." Furthermore, "discourses of progress and enlightenment were used by the socialists, these notions were, arguably, categorically different in that they did not strive to achieve Western-style secularism". In Yugoslavia, the unveiling was both symbolic of progress and ideological goal - removing the veil, at least theoretically, would allow women to enter the labor force. Hadžiristić, T., 2017, p. 198.

35 After consolidation of the new socialist state, in the late summer of 1947, a new organization and leadership of the Yugoslav Muslim Religious Community were established too. Only two months after its inauguration, the new leadership composed of prewar liberal members of Muslim community with Ibrahim Fejić at the head, issued a missive announcing the freedom of woman's choice to unveil her face in accordance with the Islamic code. Shortly afterwards, the similar official declarations were issued by the local Muslim authorities in Macedonia (Karčić, F., 2013, Stavovi vodstva Islamske zajednice u Jugoslaviji povodom zabrane nošenja zara i feredže, Anali Guzi Husrev-begove biblioteke, Vol. 42, No. 34, pp. 225-235) and Montenegro as well (Koprivica V., Muslimani Crne Gore u Socijalističkoj Federativnoj Republici Jugoslaviji (1946-1990), in: Folić, Z., Korprivica V., Kurpejović, A., (eds.), 2015, Istorija Muslimana Crne Gore 1918-2007, Podgorica, Matica Muslimanska Crne Gore). This new interpretation of the veil being in line with the socialist modernization was only an aspect of broader reforms of the Muslim institutions including the abolishment of 
of law enforcement. ${ }^{36}$ However, it can hardly remove the objection on a clearly confessional aspect of the ban: in spite of that the majority of Muslim religious servants disapproved or, at least, did not encourage this attire wearing, there was always a certain minority of imams that openly demanded their congregation to observe the veil. ${ }^{37}$ As a matter of fact, the Yugoslav law was much about to hush a refractory clergy that was not going to be kept quiet.

\subsubsection{Promoting the Veil: A Step Towards the Yugoslav Kanzelparagraph}

Article 2 of all four Yugoslav statutes prohibits forcing or persuading woman to wear the full-face veil or to cover her face as well as any action supporting the same clothing practice. Two criminal offenses provided by the Art. 4 derived from this prohibition. The first one concerns "all those who by using the force, threat, blackmail or any similar means support the wearing of the zar or the feredža or covering a woman's face" 38 while the second one involves "all those who by abuse of religious feelings, use of

sharia courts and madrasa schools. This postwar remodeling of Islam was sustainable due to the fact that until 1989, the top leaders of the Yugoslav Muslim religious community were all Partisan veterans dedicated to Tito's ideology of brotherhood and unity (Perica, V., 2002, Balkan Idols: Religion and Nationalism in Yugoslav States, Oxford, Oxford University Press, p. 74).

36 For more about a proactive role of local imams in the unveiling campaigns and enforcement of ban, see: Folić, Z., 1999, pp. 88-89; Kačar, S. 1999, pp. 40-41; For more details on enforcement of the ban, see in general: Karčić, F., 2013, Primjena zakona o zabrani nošenja zara i feredže u Bosni i Hercegovini, Novi Muallim, Vol. 14. No. 56, pp. 50-55.

37 The claim that the full-face veil is a cultural habit, and not a religious prescription of Sharia law, radically changes the legal context of whole controversy: the veil ceases to be an issue of religious liberty and, consequently of secularism. It also arises another, more fundamental, question on who decides what is a religiously inspired behavior that merits a protection: whether court has to protect every subjective religious behavior or only those behaviors that can pass some objective test, e. g. the confirmation of a religious authority that set dogmas and rites. "On the one hand, human rights law is open to claims based on the harm suffered by an individual, which is always subjective in nature. On the other hand, decision-making bodies need to protect themselves from abusive claims, and therefore cannot accept all subjective statements." (Barton, D., 2012, p. 10). Since the ECtHR is generally reluctant to the subjective understanding of the personal claims (E.g.: Xv the United Kingdom, No. 7291/75, Judgement of 4 October 1977), the official standpoint of the supreme Islam authority for a certain region or country could be used as a basis for dismissing the subjective claims. Curiously, this kind of reasoning has not been the part of the ECtHR veil-ban case-law so far.

38 As it was explained before, a specific form of this penalty, i.e., the situation when the action of persuading woman to wear the full-face veil or to cover her face is per- 
prejudices and backwardness, or in any other way do the propaganda in favor of wearing the zar or the feredža or covering a woman's face". Both criminal offenses were sanctioned alternatively by, up to two years of hard labor, or by a significant fine of 50,000 dinars.

Uncontroversial as a crime against individual liberty, the first of these two offenses was not clear enough in terms of its origin and implementation, though. Namely, there are reports on criminal court practice prior to the 1950 Yugoslav burka ban, proceeding and punishing the violent acts against woman's free choice to take off the veil. ${ }^{39}$ These reports arise at least two questions. The fact that judiciary obviously could rely on the existing penal code to prosecute the criminals and protect the unveiled women, begs the question whether the adoption of this specific criminal offense in 1950 was really necessary. This issue becomes even more plausible if one takes into account a comparative perspective: the Soviet authorities declined the proposal of similar legislation as redundant for as much as those crimes could have been already sanctioned as duress under the general Soviet Penal Code in force at the time. ${ }^{40}$ Secondly, and even more intriguing, is the question which penal code the Yugoslav courts were referring to when they stated their verdicts dated before 1950: after they had taken the full control over the state in 1945, the Yugoslav communists abolished the whole prewar legal system by voting the Law on Invalidity of Legal Acts Enacted Before 6 April 1941 and During the Enemy Occupation. According to that general abrogation law, every single piece of old regime's legislation had been declared invalid unless it complied with the new socialist order. ${ }^{41}$ In other words, it was up to the new socialist courts to evaluate ideological compatibility and applicability of the old penal code in every single case. Consequently, in order to protect the unveiling and boost the women's emancipation, the socialist judges might have easily decided to proceed on the grounds of the old Yugoslav Penal Code of 1930, by implementing its provisions on duress (i.e., Art. 242). ${ }^{42}$

formed by her inmates, a.k.a. her family members, was as envisaged as a moderately sanctioned infraction under Art. 3 of all four Yugoslav statutes.

39 For the court sentences made against the obstructions of unveiling, mostly the insults directed at the unveiled women, see: Kačar, S., 1999, p. 34.

40 Northrop, D., 2004, p. 267.

41 Zakon o nevažnosti pravnih propisa donetih pre 6. aprila 1941. godine i za vreme neprijateljske okupacije [Law on Invalidity of Legal Acts Enacted Before 6 April 1941 and During the Enemy's Occupation], Službeni list FNRJ [Official Gazette of FPR Yugoslavia], No. 86/46, 105/46, 96/47, p. 1078, Arts. 1 and 4.

42 This hypothesis seems to be as much as probable, since the assumed way of Yugoslav socialist court reasoning obviously fitted with general tendencies of that time. According to Zdenēk Kühn, one of the main drivers of judicial activism in Stalinist 
Far more interesting is the second criminal offense that sanctioned the promotion of full-face veil. The law stipulated that any act of veil-wearing promotion shall be considered as a criminal one, but it specifically emphasized the propaganda performed through the abuse of religious feelings, prejudice and backwardness. It is the 'abuse of religious feelings' that deserves more attention and gives opportunity for a more ambitious conclusion: despite the fact that this provision did not explicitly designate religious servants as the only possible perpetrators, it implicitly referred to them, making of this provision a socialist pulpit law or, at least, its very embryo.

By definition, a pulpit law is a legislation that made a crime for any cleric who makes a political statement while exercising its sacerdotal office. The first law of this kind was the so-called Kanzelparagraph of 1871 German Penal Code which stated that "Any cleric or other minister of religion shall be punished with imprisonment or incarceration of up to two years if he, while exercising his occupation or having his occupation exercised, makes state affairs the subject of announcements or discussion either in public before a crowd, in a church, or before any number of people in some other place designated for religious gathering for in such a way that it endangers the public peace." 43 Consequently, the actus reus of this crime entailed 1) religious servants, 2) doing politics, 3) exercising their sacerdotal function, 4) in public, and 5) in a way that endangers the public peace. In a word, it denounced preaching politics from a pulpit. As an expression of Bismarck's Kulturkampf targeting the church influence on the state politics, it was passed by Reichstag in late 1871, but remained practically inefficient ${ }^{44}$ to be finally abrogated in 1953 . However, the German law served as a model for many other criminal legislations, ${ }^{45}$ including

judiciary (as it was the Yugoslav one up to the early 1950s) was the woman's emancipation understood as woman's inclusion in rows of proletariat as the agent of postwar reconstruction and building of socialism. Kühn, Z., The Instrumental Use of Basic Rights by the Stalinist Judiciary, in: Sajó, A., (ed.), 2006, Abuse: The Dark Side of Fundamental Rights, Utrecht, Eleven International Publishing, p. 99.

43 Section para. 130a of the Strafgesetzbuch.

44 As any other highly controversial legislation, the pulpit law easily risked to fall into spontaneous disuse. According to Ronald Ross, it was an excessively legalistic approach, with its scrupulous regard for evidence and proof, that obviously stood in the way of the successful implementation of the Kanzelparagraph: although the police monitored religious services for possible infractions of its provisions, the charges were difficult to verify, and convictions were rare. Simply, "the police and the courts never abandoned strict procedural considerations to lash out indiscriminately at all, or even most, of those clerics accused of abusing the power of the pulpit". Ross, R. J., 1984, Enforcing the Kulturkampf in the Bismarckian State and the Limits of Coercion in Imperial Germany, The Journal of Modern History, Vol. 56, No. 3, p. 468.

45 Only a year after the German Kanzelparagraph was formally abolished, in 1954, Lyndon B. Johnson in capacity of the US Senator proposed a motion that would become the section 501(c) (3) of the federal Internal Revenue Code. This federal act prohibits 
the Yugoslav one. As a general prohibition, it was incorporated in the very core of the first Yugoslav constitution of 1921 which stated that "Religious representatives must not use their spiritual authority for political purpose in places of worship or in texts of religious nature or by exercising their official duties." 46 This constitutional declaration, however, had not been implemented before 1 January 1930 when the first Yugoslav Penal Code was enacted. ${ }^{47}$ As its Art. $400,{ }^{48}$ this pulpit law was only conditionally abrogated in 1945. It means that, as it was explained above, it might have been implemented by the socialist courts in terms of its compliance with the new socialist order. Thus, even if there are no reports of such an implementation, the latter was theoretically probable: in its early phase of consolidation, the new Yugoslav regime had been striving, by all means, to take administrative control over religious denominations and repress their reactionary propaganda. Besides, the first socialist Constitution of 1946 gave a ground for such judicial politics by a general prohibition of political abuse of religion and, more explicitly, an interdiction of political organizations established on a religious basis. ${ }^{49}$ In such a way, the 1946 Constitution

intervention in political campaigns by organizations that are exempt from the federal income tax such as schools, hospitals, social service agencies, universities, museums or charitable associations, including religious organizations. In other words, the political abstention is the condition of maintaining the tax-exempt status. Nevertheless, this prohibition does not imply any criminal sanction, and despite the fact that it prohibits only religious organizations from intervening in a political campaign for elective public offices, it still represents a legal means that effectively restrain political activities of the religious denominations in the USA. For more about this, see: Zelinsky, E. A., The Internal Revenue Code and Religious Institutions, in: Zelinsky, E. A., 2017, Taxing the Church: Religion, Exemptions, Entanglement, and the Constitution, Oxford, Oxford University Press, pp. 43-63; Johnson, S. N., 2001, Of Politics and Pulpits: A First Amendment Analysis of IRS Restrictions on the Political Activities of Religious Organizations, Boston College Law Review, Vol. 42, No. 4, pp. 875-901; O’Daniel, P. L., 2001, More Honored in the Breach: A Historical Perspective of the Permeable IRS Prohibition on Campaigning by Churches, Boston College Law Review, Vol. 42, No. 4, pp. 733-769.

46 Art. 12, line 7 of The St. Vitus Day Constitution of Kingdom of Serbs, Croats and Slovenes. According to Marko Pavlović, the main cause for adoption of Yugoslav Kanzelparagraph was the fact that priests were public officials who might abuse their position by doing favor to their political party. Pavlović, M., 2017, Kancel paragraf Vidovdanskog ustava, Anali Pravnog fakulteta u Beogradu, Vol. 65, No. 3, p. 41.

47 The 1930 Yugoslav Penal Code restated almost word for word the above-mentioned constitutional stipulation, and provided an alternative sanction of up to two years of imprisonment or a fine. Ibid., p. 45.

48 For more on Art. 400 (i.e. Kanzelparagraph) of 1930 Yugoslav Penal Code, see: Čubinski, M., 1930, Naučni i praktični komentar Krivičnog zakonika Kraljevine Jugoslavije, Beograd, Izdavačka knjižarnica Gece Kona, p. 577 or Dolenc, M., 1930, Tumač Krivičnog zakonika Kraljevine Jugoslavije, Zagreb, Tisak Tipografija D.D. Zagreb, p. 490.

49 Ustav Federativne Narodne Republike Jugoslavije [Federative People's Republic of Yugoslavia Constitution], Službeni list FNRJ [Official Gazette of FPRY], No. 10/46, 
announced a criminal legislation yet to come. The latter had complex genesis, though. Its starting point, seemingly, was the 1950 burka ban that went along with the constitutional semantics: as it was stated above, the law incriminated especially a veil-favorable propaganda performed through the abuse of religious feelings. Certainly, this piece of legislation was not a pulpit law strictly speaking - in a way it did not appoint religious servants as the only potential abusers, nor specifically limited acts of abuse on public performances such as mass religious gatherings and church services - but, it was surely its very inception..$^{50}$ Only six months later, these four state-level statutes would be complemented by the 1951 pulpit law stricto sensu within Art. 311 of the new Yugoslav federal Penal Code providing that: "Religious representative abusing the free exercise of religious affairs and freedom of worship to the purpose in opposition to the constitutional order shall be incarcerated up to two years." ${ }^{11}$ Furthermore,

Art. 25, pp. 77-78. The succeeding Yugoslav Constitutional acts of 1963 and of 1974, in their Arts. 46 and 176 respectively, retained the general prohibition of the political abuse of church and religion, but did not explicitly stipulate any interdiction of confessional political organizations.

50 It would be further fortified by a similar federal prohibition of political abuse of religion. For more on this federal legislation see: Božić, M., 2019, Neither Secular State nor Laical Republic? Legal Position of Religious Communities in Communist Yugoslavia - Legal Framework Analysis, Pravni zapisi, Vol. 10, No. 1, pp. 50-51.

51 Krivični zakonik [Penal Code], Službeni list FNRJ [Official Gazette of FPRY], No 13/51, pp. 185-224. At least a part of the Yugoslav socialist theory of criminal law was ready to qualify this Art. 311 as a pulpit law, or Kanzelparagraph, e.g., Tahović, J., 1961, Krivično pravo posebni deo, Beograd, Savremena administracija, p. 426. As a result of the late 1960 s and the early 1970 s the constitutional reforms, the penal legislation competencies had been changed so that the pulpit law provision had been eliminated from the federal Penal Code and incorporated into Penal Codes of the six Yugoslav federated states: Кривични законик CР Србије [Penal Code of SR Serbia], Службени іласник СР Србије [Official Gazette of SR Serbia], No. 26/77, Art. 238, p. 1367; Krivični zakonik SR Hrvatske [Penal Code of SR Croatia], Narodne novine SR Hrvatske [People's Newspapers of SR Croatia], No. 25/77, Art. 217, p. 404; Kaznenski zakon SR Slovenije [Penal Code of SR Slovenia], Uradni list SR Slovenije [Official Gazette of SR Slovenia], No. 12/77, Art. 236, p. 664; Krivični zakon SR Bosne i Hercegovine [Penal Code of SR Bosnia and Herzegovina], Službeni list Bosne i Hercegovine [Official Gazette of SR Bosnia and Herzegovina], No. 16/77, Art. 222, p. 480; Кривичен закон на СР Македонија [Penal Code of SR Macedonia], Службен весник на СР Макеgонија [Official Gazette of SR Macedonia], No. 25/77, Art. 227, p. 516; Кривични закон СР Црне Горе [Penal Code of SR Montenegro], Службени тисти СР Црне Горе [Official Gazette of SR Montenegro], No. 22/77, Art. 226, p. 311; (The Penal Code of Autonomous Province of Vojvodina and the Penal Code of Autonomous Province of Kosovo did not contain this provision. According to Art. 2 of the Serbian Penal Code, Art. 238 of the latter was in force in both Autonomous Provinces). This transfer of competencies from federal to state legislation did not affect the sense of the prohibition, though. The wording of the 1977 provisions remained identical to the old, the 1951 federal one. 
the Kanzelparagraph was embedded in the Protocol on the Negotiations Between Yugoslavia and the Holy See signed in $1966 .{ }^{52}$ According to the Protocol, catholic priests' duty was to remain within the limits of their religious service, so they could not abuse their religious functions for political purposes. The common thread in these series of regulations is the abuse of religion as a concept that the earlier prewar Yugoslav legal system was not familiar with. ${ }^{53}$ The idiosyncrasy of the notion was not merely lexical, but a conceptual one: defined as a political use of religion, this abuse remains in close connection to the Marxist understanding of religion in general, and to the specific way of functioning of Yugoslav socialism in particular.

Commonly considered as a relic of the past, religion has not always been seen as a potential threat to the socialist state and order. An openly hostile attitude of postwar Marxist doctrine in Yugoslavia eventually evolved to acceptance of a relatively peaceful coexistence, ${ }^{54}$ but had never abandoned

52 Protokol o razgovorima koji su vođeni između predstavnika vlade Socijalističke Federativne Republike Jugoslavije i predstavnika Svete Stolice [Protocol on Negotiations Between the Representatives of the Government of Socialist Federative Republic of Yugoslavia and the Representatives of the Holy See], Službeni list SFRJ - Medunarodni ugovori i drugi sporazumi [Official Gazette of the SFRY - International Treaties and Other Agreements], No. 11/66, pp. 984-986, the section II, point 2. Even if the 1966 Protocol was more a Memorandum of understanding than an international treaty and despite the fact that the extent of religious limits has never been clear and certain, this stipulation stays perfectly in line with the idea of Kanzelparagraph. For more on this see: Božić, M., 2020, Tito’s Concordat - The 1966 Protocol on the Negotiations Between Yugoslavia and the Holy See from a Legal Perspective, Pravni zapisi, Vol. 11, No. 2, pp. 554-579.

53 Legal definition of 'political abuse of religion' had been constantly evolving: $1946 \mathrm{Yu}$ goslav Constitution referred to abuse of both, the church - as an institutional - and religion - as a phenomenon. Burka ban from the late 1950s incriminated abuse of 'religious feelings', while 1951 federal Penal Code penalized the abuse of 'free exercise of religious affairs and freedom of worship'. On the other hand, 1953 federal act on legal status of religious communities prohibited any political abuse of "religious institutions, religious affairs, religious rituals, religious press, religious instruction and other forms of manifestation of religious feelings".

54 In the Marxist doctrinal writings on religion dated from the mid-1960s to the late 1980s prevail a common place that religion is expected to disappear progressively with the further development of the socialist society. Therefore, not only the administrative measures against religion were really necessary, but they could have turned out to be counterproductive in a way they might have risen social tension and provoked instability. Hence, if the clericalism - as the political interference of religion in state affairs remained an act of crime, the open anticlerical behavior of some party members - so called sectarianism, also became an inadmissible and harshly criticized stance up to the mid-1960s. E.g.: Frid, Z., 1971, Religija u samoupravnom socijalizmu, Zagreb, Centar za društvene djelatnosti omladine RK SOH, p. 40; Kurtović, T., 1978, Crkva i religija u socijalističkom samoupravnom društvu, Beograd, Rad, p. 376; Cvitanović, I., 1987, Sloboda religije u socijalističkom samoupravnom društvu, Novi Sad, Dnevnik, p. 19. 
its basic premises: as a strictly private affair, religion was protected by the Constitution in terms of religious freedom, but without any licit role in political life of the socialist system. ${ }^{55}$ For any church and clergymen, this did not mean their complete exclusion from the politics, but rather a strictly controlled inclusion into it. Although the Yugoslav communist party did not tolerate any political opposition, it did not deny the plurality of interests and established the so-called Socialist Union as a forum designed to debate, converge and harmonize distinctive regards on the given topic. Nobody, including religious servants, ${ }^{56}$ was allowed to autonomously step forward and take a political stance beyond this state-controlled body. Preaching a politically inspired sermon in church or mosque was considered as an abuse of religious freedom aimed against the established order - an act of clericalism.

Once put it in perspective with this Marxist doctrine of clericalism, the wording of Art. 4 of the 1950 Yugoslav law becomes more worth telling: as a felony, the promotion of full-face veil by abusing religious feelings, i.e., by using the same to a political purpose, targeted those who were, in the first place, in capacity to perform such (ab)use: the religious authority capable to incite these spiritual, but highly institutionalized emotions. More than at anyone else, the letter of 1950 law was directed at the disobedient Yugoslav imams. ${ }^{57}$

\section{CONCLUSiON}

Enacted in the early 1950s, the Yugoslav burka ban is formally still binding. None of the four Yugoslav republics that voted the ban did abrogate or amended this legislation after the collapse of socialism and disintegration of the common state. Formally still in force, the ban is effectively obsolete because of its disuse, though. Fully applied after its enactment, it fulfilled its purpose soon and lost on significance: long before the end of the 1950s, veiled women on the Yugoslav streets became only an incident. The indubitable success of the law testifies its meaningfulness. It also highlights a sharp contrast with the contemporary burka bans in Europe: unlike some modern democracies who resort to the ban in order to

55 E.g.: Frid, Z., 1971, pp. 10-11, 36, 71-72; Kurtović, T., 1978, pp. 136-137, 146, 217, 344 and 173-174; Samardžić, R., 1985, Religija i vjerske zajednice u Socijalističkoj Federativnoj Republici Jugoslaviji, Beograd, Rad, pp. 42, 56 and 61; Cvitanović, I, 1987, pp. 39-40.

56 More precisely, religious servants were free to preach politics when it was favorable to socialist state order and were welcome to take part in work of the Socialist Union. E.g.: Frid, Z., 1971, p. 93; Kurtović, T., 1978, p. 348.

57 There are reports on high officials of the Yugoslav Muslim religious leadership that they were persuading and convincing imams who still hesitated or resisted to accept unveiling. See: Radić, R., 1995, p. 259 (fn. 396). 
protect the gender equality allegedly threatened from a tiny minority of veiled women, the Yugoslav socialism was confronting a rooted and vivid tradition as a de facto setback for women's inclusion in the public life and working force. Hence, there is an asymmetry: enabled by the law, the gender equality seems to be a justified cause then, but only a low-rated excuse before the ECtHR now.

Yet, the both legislative politics share a common paternalistic aim: to free woman and make her a part of unique and indivisible political (either republican or proletarian) nation that does not admit communitarian deviations. In the most prominent western democracies that have introduced burka ban first, such as France or Belgium, this restriction is explicitly connected to their concept of religiously neutral i.e., laical state highly intolerant to religious interference in politics. In the socialist Yugoslavia, the same logic was less obvious, but implicitly grounded in the Marxist doctrine: religion was understood as a reactionary institution that was tolerated but reduced to a strictly private affair, without any recognized role in public life of the new socialist state. The very same idea was embodied in the Yugoslav full-face veil ban which did not prohibit only veiling as such, but also its promotion on a religious basis. The abuse of religious feelings, forbidden by the law, was not a capricious gesture of the Yugoslav lawmaker but an emanation of systemic legal policy grounded on the socialist Constitution and elaborated through further criminal legislation. Keeping religion out of politics, the latter culminated in the 1951 socialist pulpit law that incriminated all religious servants preaching politics in public.

A priori excluding religion as such from open public space and free debate, this so-called militant secularism, has always been away from theory and practice of liberal democracy. Being open and inclusive, a democratic society of women and men equal in their rights and liberties does not favorize or discriminate anybody on religious basis. As religious neutrality of the state, secularism is a guarantee of equality in religious liberty. When it is invoked as an absolute value in order to justify oppression against all "those who are perceived as alien and therefore unworthy of inclusion in the body politic" 58 secularism loses its cogency and sense. As a distorted concept, this militant secularism is often wrongly misinterpreted as an expression of militant democracy restraining the liberties of those who use them in a way to destroy liberal order. ${ }^{59}$ There should not be

58 Ginsburg, T., Huq, A., 2018, How to Save a Constitutional Democracy, Chicago-London, The University of Chicago Press, p. 171 (fn. 10).

59 For more about the ongoing debate on the concept and limits of militant democracy, see: Beširević, V., 2022, Militant Democracy and Populism: A Response to Tom Ginsburg and Aziz Huq, in: Gardašević, Đ., Gotovac, V., Zrinščak, S., (eds.), 2022, Liber Amicorum Josip Kregar, Zagreb, Pravni fakultet Sveučilišta u Zagrebu, forthcoming. 
any ambiguity, though. Even if militant, democracy is necessarily secular. Militant secularism, however, can never be democratic.

\section{BIBLIOGRAPHY}

1. Ballinger P., Ghodsee, K., 2011, Socialist Secularism. Religion, Modernity, and Muslim Women's Emancipation in Bulgaria and Yugoslavia, 1945-1991, Aspasia, Vol. 5, No. 1, pp. 6-27.

2. Barton, D., 2012, Is the French Burka Ban Compatible with International Human Rights Law Standards? Essex Human Rights Review, Vol. 9, No. 1, pp. 1-27.

3. Behiery, V., 2014, A Short History of the (Muslim) Veil, Implicit Religion, Vol. 16, No. 4, pp. 413-441.

4. Beširević, V., 2022, Militant Democracy and Populism: A Response to Tom Ginsburg and Aziz Huq, in: Gardašević, Đ., Gotovac, V., Zrinščak, S., (eds.), 2022, Liber Amicorum Josip Kregar, Zagreb, Pravni fakultet Sveučilišta u Zagrebu, forthcoming.

5. Bonfiglioli, C., 2012, Revolutionary Networks: Women's Political and Social Activism in Cold War Italy and Yugoslavia (1945-1957), doctoral dissertation, Utrecht University.

6. Božić, M., 2019, Neither Secular State nor Laical Republic? Legal Position of Religious Communities in Communist Yugoslavia - Legal Framework Analysis, Pravni zapisi, Vol. 10, No. 1, pp. 40-64.

7. Božić, M., 2020, Tito's Concordat - The 1966 Protocol on the Negotiations Between Yugoslavia and the Holy See from a Legal Perspective, Pravni zapisi, Vol. 11, No. 2, pp. 554-579.

8. Clayer, N., Behind the veil: the reform of Islam in interwar Albania or the search for a "modern" and "European" Islam, in: Cronin, S., (ed.), 2014, Anti-Veiling Campaigns in the Muslim World - Gender, Modernism and the Politics of Dress, New York, Routledge, pp. 231-251.

9. Cronin, S., Introduction: coercion or empowerment?, Anti-veiling campaigns: a comparative perspective, in: Cronin, S. (ed.), 2014, Anti-Veiling Campaigns in the Muslim World - Gender, Modernism and the Politics of Dress, New York, Routledge, pp. 1-36.

10. Cvitanović, I., 1987, Sloboda religije u socijalističkom samoupravnom društvu [Freedom of Religion in Socialist Selfmenagement Society], Novi Sad, Dnevnik.

11. Čubinski, M., 1930, Naučni i praktični komentar Krivičnog zakonika Kraljevine Jugoslavije, [Scholar and Practical Commentary on Penal Code of theKingdom of Yugoslavia] Beograd, Izdavačka knjižarnica Gece Kona.

12. Dolenc, M., 1930, Tumač Krivičnog zakonika Kraljevine Jugoslavije [Interpretation of Penal Code of Kingdom of Yugoslavia], Zagreb, Tisak „Tipografija” D.D. Zagreb.

13. Folić, Z., 1999, Skidanje zara i feredže u Crnoj Gori 1947-1953 [Unveiling in Montenegro between 1947 and 1953], Istorijski zapisi, Vol. 72, No. 3-4, pp. 73-90. 
14. Frid, Z., 1971, Religija u samoupravnom socijalizmu [Religion in Selfmanagement Socialism], Zagreb, Centar za društvene djelatnosti omladine RK SOH.

15. Ginsburg, T., Huq, A., 2018, How to Save a Constitutional Democracy, ChicagoLondon, The University of Chicago Press.

16. Hadžiristić, T., 2017, Unveiling Muslim Women in Socialist Yugoslavia: The Body between Socialism, Secularism, and Colonialism, Religion \& Gender, Vol. 7, No. 2, pp. 184-203.

17. Jahić, A., 2017, Muslimansko žensko pitanje u Bosni i Hercegovini 1908-1950 [Muslim woman's cause in Bosnia and Herzegovina 1908-1950], Zagreb, Bošnjačko nacionalno vijeće za grad Zagreb.

18. Johnson, S. N., 2001, Of Politics and Pulpits: A First Amendment Analysis of IRS Restrictions on the Political Activities of Religious Organizations, Boston College Law Review, Vol. 42, No. 4, pp. 875-901.

19. Kačar S., 1999, Sudari svjetova (o akciji skidanja zara i feredže u Sandžaku) [Clash of the Worlds (On the Campaign on Unveiling in Sadnžak Region)], Almanah, Vol. 2, No. 7-8, pp. 31-44.

20. Kačar S., 2001, Zarozavanje zara [Lifting the Veil], Podgorica, Almanah.

21. Kamp, M., Women-initiated unveiling: state-led campaigns in Uzbekistan and Azerbaijan, in: Cronin, S. (ed.), 2014, Anti-Veiling Campaigns in the Muslim World - Gender, modernism and the politics of dress, New York, Routledge, pp. 205-228.

22. Karčić, F., 2013, Primjena zakona o zabrani nošenja zara i feredže u Bosni i Hercegovini [Enforcement of Law on Ban of the Zar and the Feredža in Bosnia and Hercegovina], Novi Muallim, Vol. 14, No. 56, pp. 50-55.

23. Karčić, F., 2013, Stavovi vodstva Islamske zajednice u Jugoslaviji povodom zabrane nošenja zara i feredže [Attitude of Yugoslavia Muslim Community Leadership on the Ban of the Zar and the Feredža], Anali Guzi Husrev-begove biblioteke, Vol. 42, No. 34, pp. 225-235.

24. Kladničanin, F., 2020, Peča [Petcha], Novi Pazar, Akademska inicijativa Forum 10.

25. Klajn, I., Šipka, M., 2006, Veliki rečnik stranih reči i izraza [Great Dictionary of Foreing Words and Phrases], Novi Sad, Prometej.

26. Koprivica V., 2015, Muslimani Crne Gore u Socijalističkoj Federativnoj Republici Jugoslaviji (1946-1990) [Muslims of Montenegro in SFRY (1946-1990)], in: Folić, Z., Koprivica V., Kurpejović, A. (eds.), Istorija Muslimana Crne Gore 1918-2007 [The History of Muslims of Montenegro 1918-2007], Podgorica, Matica Muslimanska Crne Gore.

27. Kühn, Z., The Instrumental Use of Basic Rights by the Stalinist Judiciary, in: Sajó, A. (ed.), 2006, Abuse: The Dark Side of Fundamental Rights, Utrecht, Eleven International Publishing, pp. 99-110.

28. Kurtović, T., 1978, Crkva i religija u socijalističkom samoupravnom društvu [Church and Religion in Socialist Selfmanagement Society] Beograd, Rad.

29. Mancini, S., European Law and the Veil: Muslim Women From Victims to Emblems of the Enemy, in: Melloni, A., Cadeddu, F. (eds.), 2019, Religious Literacy, Law and History. Perspectives on European Pluralistic Societies, New York, Routledge, pp. 127-136. 
30. Massell, J. G., 1974, The Surrogate Proletariat: Moslem Women and Revolutionary Strategies in Soviet Central Asia, 1919-1929, Princeton, Princeton University Press.

31. Milinović, D., Petakov, Z., 2010, Partizanke: žene u Narodnooslobodilačkoj borbi [Partisan Women: Ladies in People’s Liberation War], Novi Sad, Cenzura \& Rosa Luxemburg Stiftung.

32. Möschel, M., Veiled Issues in European Courts, in: Calvi, G., Fadil, N., (eds.), 2011, Politics of Diversity. Sexual and Religious Self-Fashioning in Contemporary and Historical Contexts, Florence, European University Institute, Department for History and Civilization, pp. 5-18.

33. Northrop, D., 2004, Veiled Empire, Gender \& Power in Stalinist Central Asia, Ithaca and London, Cornell University Press.

34. O'Daniel, P. L., 2001, More Honored in the Breach: A Historical Perspective of the Permeable IRS Prohibition on Campaigning by Churches, Boston College Law Review, Vol. 42, No. 4, 733-769.

35. Pavlović, M., 2017, Kancel paragraph Vidovdanskog ustava [Kanzelparagraph of St. Vitus Constitution], Anali Pravnog fakulteta u Beogradu, Vol. 65, No. 3, pp. 28-49.

36. Perica, V., 2002, Balkan Idols: Religion and Nationalism in Yugoslav States, Oxford, Oxford University Press.

37. Radić, R., 1995, Država i verske zajednice u Srbiji 1945-1953, [State and religious communities in Serbia between 1945 and 1953], Beograd, Institut za noviju istoriju Srbije.

38. Ross, R. J., 1984, Enforcing the Kulturkampf in the Bismarckian State and the Limits of Coercion in Imperial Germany, The Journal of Modern History, Vol. 56, No. 3, pp. 456-482.

39. Samardžić, R., 1985, Religija i vjerske zajednice u Socijalističkoj Federativnoj Republici Jugoslaviji [Religion and Religious Communities in Socialist Federative Republic of Yugoslavia], Beograd, Rad.

40. Simić, I., 2018, Soviet Influences on Postwar Yugoslav Gender Policies, Palgrave Macmillan.

41. Škaljić, A., 1985, Turcizmi u srpskohrvatskom-hrvatskosrpskom jeziku [Terms of Turkish Origine in Serbo-Croatian Language], Sarajevo, Svjetlost.

42. Wallach Scott, J., 2007, The Politics of The Veil, Princeton and Oxford, Princeton University Press.

43. Zelinsky, E. A., The Internal Revenue Code and Religious Institutions, in: Zelinsky, E. A., 2017, Taxing the Church: Religion, Exemptions, Entanglement, and the Constitution, Oxford, Oxford University Press, pp. 43-63.

\section{LEgAL ACTS}

1. Krivični zakonik Kraljevine Jugoslavije [Penal Code of Kingdom of Yugoslavia], Službene novine Kraljevine Srba, Hrvata i Slovenaca [Official Gazette of the Kingdom of Serbs, Croats and Slovenes], No. 33/29, pp. 158-186. 
2. Zakon o nevažnosti pravnih propisa donetih pre 6. aprila 1941. godine i za vreme neprijateljske okupacije [Law on Invalidity of Legal Acts Enacted Before 6 April 1941 and During the Enemy's Occupation], Službeni list FNRJ [Official Gazette of FPR Yugoslavia], No. 86/46, 105/46, 96/47, p. 1078.

3. Zakon o zabrani nošenja zara i feredže [Statute on Ban of Wearing the Zar and the Feredža], Službeni list NR Bosne i Hercegovine [Official Gazette of PR Bosnia and Hercegovina], No. 32/50, p. 427.

4. Закон за забрана да се носи зар и фереџе [Statute on Ban of Wearing the Zar and the Feredža], Службени весник на НР Макеgонија [Official Gazette of PR Macedonia], No. 1/51, p. 1.

5. Закон о забрани ношења зара и фереџе [Statute on Ban of Wearing the Zar and the Feredža], Службени іласник НР Србије [Official Gazette of PR Serbia], No. 4/51, pp. 84 and 85.

6. Закон о забрани ношења зара и фереџе [Statute on Ban of Wearing the Zar and the Feredža], Службени листи НР Црне Горе [Official Gazette of PR Montenegro], No. 31/50, p. 229.

7. Ustav Kraljevine Srba, Hrvata i Slovenaca [Constitution of the Kingdom of Serbs, Croats and Slovenes], Službene novine Kraljevine Srba, Hrvata i Slovenaca [Official Gazette of the Kingdom of Serbs, Croats and Slovenes], No. Special 142a.

8. Ustav Federativne Narodne Republike Jugoslavije [Federative People’s Republic of Yugoslavia (FPRY) Constitution], Službeni list FNRJ [Official Gazette of FPRY], No. 10/46, p. 73-94.

9. Krivični zakonik [Penal Code], Službeni list FNRJ [Official Gazette of FPRY], No. 13/51, pp. 185-224.

10. Krivični zakon SR Bosne i Hercegovine [Penal Code of SR Bosnia and Herzegovina], Službeni list Bosne i Hercegovine [Official Gazette of SR Bosnia and Herzegovina], No. 16/77, pp. 453-483.

11. Krivični zakonik SR Hrvatske [Penal Code of SR Croatia], Narodne novine SR Hrvatske [People's Newspapers of SR Croatia], No. 25/77, pp. 379-407.

12. Кривичен закон на CP Македонија [Penal code of SR Macedonia], Службен весник на СР Макеgонија [Official Gazette of SR Macedonia], No. 25/77, pp. 489-519.

13. Kaznenski zakon SR Slovenije [Penal Code of SR Slovenia], Uradni list SR Slovenije [Official Gazette of SR Slovenia], No. 12/77, pp. 634-667.

14. Кривични законик СР Србије [Penal Code of SR Serbia], Службени іласник CP Cрбије [Official Gazette of SR Serbia], No. 26/77, pp. 1341-1369.

15. Кривични закон СР Црне Горе [Penal code of SR Montenegro], Службени листи СР Црне Горе [Official Gazette of SR Montenegro], No. 22/77, pp. 282-314.

16. Protokol o razgovorima koji su vođeni između predstavnika vlade Socijalističke Federativne Republike Jugoslavije i predstavnika Svete Stolice [Protocol on negotiations between the representatives of the Government of the Socialist Federative Republic of Yugoslavia and the representatives of the Holy See], Službeni list SFRJ - Medunarodni ugovori i drugi sporazumi [Official Gazette of the SFRY - International treaties and other agreements], No. 11/66, pp. 984-986. 


\section{CASE LAW}

1. ECtHR, S. A. S. v. France, No. 43835/11, Judgement of 1 . July 2014, [GC].

2. ECtHR, Dakir v. Belgique, No. 4619/12, Judgement of 11 July 2017.

3. ECtHR, Belcacemi et Oussar v. Belgique, No. 37798/13, Judgement of 11 July 2017.

\section{DEMISTIFIKOVANI ZAKON: \\ O ZABRANI VELA, KANCELPARAGRAFU I MILITANTNOM SEKULARIZMU U SOCIJALISTIČKOJ JUGOSLAVIJI}

\section{Marko Božić}

\section{APSTRAKT}

Detaljno proučena s aspekta svoje političke pozadine, jugoslovenska zabrana zara i feredže s početka pedesetih godina XX veka do danas ostaje izvan polja interesovanja istoričara prava. Izlažući ovo jugoslovensko zakonodavstvo normativoj analizi i poređenju sa sličnim savremenim zabranama burke i nikaba, ovaj rad dolazi do zaključaka koji nadilaze dosadašnje istoriografske studije. Mada kratka po formi, jugoslovenska zabrana zara i feredže predstavljala je složeno zakonodavstvo kojim je nesumnjivo zabranjeno pokrivanje ženskog lica, ali su uvedena i krivična dela protiv protivnika skidanja zara i feredže, kao i zametak budućeg socijalističkog kancelparagrafa, tzv. predikaoničkog zakona. Militantna orijentacija ovog zakonodavstva, koje se otvoreno suprotstavilo jednoj verski motivisanoj praksi, samo se naizgled razlikuje od umerenijeg izraza savremenih zakonskih zabrani burke i nikaba. Produbljena analiza ideološkog opravdanja jugoslovenskog zakonodavstva, međutim, ukazuje na bitnu sličnost sa zabranama savremenih laičkih država: u oba slučaja radi se o akciju paternalističke države koja za cilj ima isključivanje religije iz političke sfere društvenog života i javne rasprave. Kao takva, analiza jugoslovenske zabrane zara i feredže doprinosi boljem razumevanju militantnog sekularizma kao savremene, ali nikako i nove kontroverze.

Ključne reči: zabrana burki, kancelparagraf, socijalistička Jugoslavija, socijalistički sekularizam, militantni sekularizam.

Article History:

Received: 29 September 2021

Accepted: 6 December 2021 